\title{
THE FOREST WARRIOR OF WALISONGO ISLAMIC BOARDING SCHOOL TUBAN: Supporting Students as Ecotheology Based Forest Conservator
}

Fikri Mahzumi, Suhermanto, and Iffah

Universitas Islam Negeri Sunan Ampel Surabaya, Indonesia

E-mail: fikrimahzumi@uinsby.ac.id

\begin{abstract}
This study tried to explore the subject of Noer Nasroh Hadiningrat who had found an eco-theological awareness at the Walisongo Islamic Boarding School in Tuban. Ecotheology is an interesting topic in academic studies today. The ecological paradigm that rests on the spirit of this religion is believed to be able to overcome the environmental crisis happening now. The focus of this study seeks to explain how the subject's conception of ecotheology, what actions are carried out? And how sustainability and implications are for the community? Using an ethnographic approach, this study focuses on epic and emic data obtained from the explanation of the subject and facts in the research field. The results of this study found that the ecotheology conception initiated by the subject was a religious reflection that originated from the primary text of Islam combined with traditional wisdom. The establishment of the State Vocational High School (SMKN) is a concrete manifestation of the subject's efforts to integrate beliefs, traditions, and forestry so that they manifest themselves in concrete actions such as reforestation, conservation, and changes in public awareness of the urgency of forest conservation. In the aspect of continuity, the existence of Forestry Vocational Schools is a forum for printing students who have an awareness of forest conservation as well as being able to seek life from it.
\end{abstract}


The idea of Kiai Noer also received support from sons, the government, and the community. This ecotheology conception has also inspired other pesantren to form a similar ecological paradigm.

Kajian ini berusaha mendalami subjek Noer Nasroh Hadiningrat yang telah menemukan suatu kesadaran ekoteologis di Pondok Pesantren Walisongo Tuban. Ekoteologi menjadi topik menarik dalam kajian akademik dewasa ini. Paradigma ekologi yang berpijak pada spirit agama ini, diyakini mampu mengatasi krisis lingkungan hidup yang kini tengah terjadi. Fokus kajian ini berusaha menjelaskan bagaimana konsepsi subjek tentang ekoteologi, apa aksi-aksi yang dilakukan, bagaimana keberlanjutan dan implikasnya bagi masyarakat. Dengan menggunakan pendekatan etnografis, penelitian ini fokus pada data epic dan emic yang diperoleh dari penjelasan subjek dan fakta-fakta di lapangan. Hasil penelitian ini menemukan bahwa konsepsi ekoteologi yang digagas subjek merupakan refleksi keagamaan yang bersumber dari teks primer Islam yang dipadukan dengan kearifan tradisi. Pendirian Sekolah Menengah Kejuruan Negeri (SMKN) Kehutanan menjadi wujud konkret upaya subjek mengintegrasikan antara keyakinan, tradisi, dan ilmu kehutanan sehingga berwujud pada aksi nyata seperti reboisasi, konservasi, dan perubahan kesadaran masyarakat akan urgensi konservasi hutan. Pada aspek kontinuitas, keberadaan SMKN Kehutanan menjadi wadah pencetak santri yang memiliki kesadaran terhadap pelestarian hutan sekaligus bisa mencari hidup darinya. Gagasan Kiai Noer pun mendapat dukungan dari putra, pemerintah, dan masyarakat. Konsepsi ekoteologi ini juga telah menginspirasi pesantren lain untuk merumuskan paradigma ekologis serupa.

Keywords: ecotheology; forest; Islamic boarding school

Received: September 24, 2018; Accepted: 19 June, 2019

\section{Introduction}

"No survival of our globe without a global ethic, a world ethic, supported by both the religious and the non-religious" (Kung 2007). | Hans Kung - Islam, Past, Present and Future

The environmental issue is a big concern in Islam. There are environmental themes found in Islamic primary sources; several surahs in 
the Quran use flora and fauna terms. The examples of these are surah al-Tin (Fig tree) and al-Baqarah (Cow) and many more (al-Qardhawi 2002, 77; Mahzumi 2018). Beside the names of the surah, the verses in Quran use words (lafz) with an environmental theme such as water ( $m \hat{a})$, mountain (jabâl), river (nahr), tree (shajarah), etc. The word shajarah and its derivation are mentioned twenty-five times. It is not only mentioned in the Quran but also hadith as well. Some hadiths discuss the environment. One of them is the hadith narrated by Imam Muslim related to tree planting advice, "No Muslim plants a tree except one will get something from the tree, and it becomes alms for him/her, and the stolen one becomes alms. Whatever is eaten by animals from the tree, then it becomes alms. What is eaten by birds from the tree, then it becomes alms. No one took it from the tree except being alms for him (Muslim 1991, no. 1552, vol. 3, 1188).”

However, the beautiful ecological image of Quran and the evocative messages from Prophet's hadith turned out to be inversely proportional to the harsh reality of environmental condition, that is increasingly in crisis because of human hands (Fata 2014). The indications of the environmental crisis are: 1) climate change; 2) depletion of the ozone layer; 3) depletion of natural resources; 4) large scale clearing of tropical rain forests; 5) loss of biodiversity; and 6) diversity of pollution. Facts and crises plaguing the earth have shown how the universe is increasingly experiencing crisis day by day because of human's wrong paradigm in understanding the relation among entities in the universe; among himself, cosmos, and God (Nasr 1996; Özdemir 1998). The environmental crisis threat is highly felt when ecological disasters are increasing (Udin 2016, 356).

As a religious country, in which the majority of the population is Muslim, ideally, Indonesia does not ignore the responsibility in overcoming the ecological problem as explained above. However, the condition of environmental life in Indonesia each year is experiencing degradation and increasingly troubling. Throughout 2018, National Board of Disaster Management (BNPB) recorded 1.999 disasters in Indonesia (BNPB: Selama 2018, Ada 1.999 Kejadian bencana 2018) and 96,9 \% of those is hydrometeorological disasters (Kaleidoskop Bencana Lingkungan 2012: Degradasi Hutan Melaju, Banjir Menerjang Manusia 2012). It means that the disasters are mostly caused by environmental damage rather than geological factor such as landslide disaster in Ponorogo on April, $1^{\text {st }} 2017$. Based on the environmental experts' investigation, the disaster is the accumulative impact of the environmental destruction done by local people 
(Ini Penyebab Longsor di Ponorogo Hasil Penelitian Tim UGM 2017). This environmental crisis is aggravated by low public awareness and the government effort in running green enforcement.

The intensity of disaster caused by environmental destruction gives a valuable lesson for Indonesia, at least, that disaster reminds us about environmental preservation. Therefore, it needs a plan and real action to overcome and to do multi-approach disaster mitigation. It can be legislation/policy or make society aware of the urgency of harmonizing the environment. The awareness can be done by resting on long-held ecological wisdom in the structure of religious personal cognitive (Matthew 2014, 251). One step that can be a role model is ecotheology. Principles of religious belief that have been deeply embedded in humanity should be a starting point of the ecological-progressive ethical formulation. By doing this, it is expected that the environmental damage can be prevented so that life sustainability can be saved or at least the damage can be inhibited.

As the center of strengthening religiosity and planting, Islamic boarding schools should be involved in campaign pro-ecological programs and religious aspects. The urgency of their involvement in this case is supported by Monika Arnez's thesis entitled Shifting Notions of Nature and Environmentalism in Indonesian Islam mentioning that environmentally friendly movement in Indonesia is an induction of belief values ('aqîlah) supported by Islamic organization, especially the people in Islamic boarding schools (Arnez 2014, 75). Like Arnez' explanation, Fachruddin Mangunjaya who focuses on the study of the living environment and climate change mentions that Islamic boarding school community can be a foundation to develop and run ecological programs as well as actions in Indonesia. The wealth of Islamic boarding school, knowledge tradition, and powerful social strength can be the basis of ecological effort formulation as well as its implementation (Mangunjaya 2005).

A large quantity and strong sub-system in the Islamic boarding school become a reason to use Islamic boarding school subjects to overcome the ecological crisis in Indonesia. Therefore, it is crucial to strengthen the awareness, role, and involvement of Islamic boarding school in running conservation using religious value to be the core of knowledge in Islamic boarding school. One of them is building the ecotheology paradigm. From the aspect of quantity, in the database of Islamic boarding school (PDPP/Pangkalan Data Pondok Pesantren), Ministry of Religious Affairs mentioned that the total number of Islamic boarding schools in Indonesia 
until 2015 had reached 25,938 units. The total number of Islamic students (santri) has reached 3,962,700 people coming from the entire archipelago: Sumatera, Java, Kalimantan, Sulawesi, and Papua (Statistik Pesantren 2018).

Meanwhile, based on the institutional quantity, an Islamic boarding school has already been decided as an exemplary religious, educational institution. These two aspects emphasize that the position of Islamic boarding school can rely upon as the center of study and the implementation of ecotheology. The Islamic boarding school has a chance to be a center of ecological, ethical formulation as well as a center of society transformation in the ecological field.

There are some Islamic boarding schools already established as centre of religious-based ecological ethic formulation and as a society transformative center in the field of ecology such as Pabelan Islamic boarding school, Magelang Central Java, An Nuqaya, Sumenep East Java, Maslakul Huda, Pati Central Jawa, Darunnaja, Jakarta, and Nurul Haramain, Lombok West Nusa Tenggara. The formulation of ecological ethic starts from induction of Islamic boarding school subjects towards the Quran's doctrine and hadith on human's responsibility to keep Allah's trusteeship, that is the environment. The embodiment of the meaning of khalîfat Allâh fî al-ard (Q.S. al-Baqarah [2]: 30) gives the ecological awareness as a solution to overcome the ecological crisis on Earth (Khitam 2011; Islam 2012 , 91). Several efforts have been formulated through various Islamic knowledge. They aim to establish "green Islamic boarding school," which has a role as a mover and mobilizer to run a green consciousness towards society. Yet, academic studies on Islamic boarding school and its involvement in ecological movement as done by Maghfur has examined the importance of environmental education (Maghfur 2010), Khitam has attempted to explore the role of pesantren on environmental change (Khitam 2016) and Aulia et al. have studied the management of pesantrenbased environment (Aulia, Isnaini, and Khumairoh 2017). However, they have not given a proper explanation of how the intensity and sustainability of ecological movement are formulated by Islamic boarding school subjects and its actualization. Furthermore, only a few studies have particularly discussed the theme of ecotheology related to the forest. Completing the previous studies, this study took one of the subjects from Islamic boarding schools in Tuban, Walisongo Islamic boarding school (written as PP. Walisongo). 
In PP. Walisongo, located on Ngomang village, Singgahan Subdistric, Tuban Regency, ecotheology paradigm is not only formulated in the level of ideas, but also praxis form. It is presented by K.H. KPP. Noer Nasroh Hadiningrat (written as Kiai Noer) as the school leader. Big vision and mission about forest saving lead him to formulate the kalam rimba (forest words) paradigm. It is a view rooted in religious value for the ecological mission. He is called "Forest Warrior" because of his ideas and ecological actions. Fikri Mahzumi states that one real aspect of the forest paradigm is Kiai Noer's effort to create Islamic students as forest conservator through SMKN Kehutanan (state forestry vocational high school). His ecological paradigm inspires other Islamic boarding schools around PP. Walisongo. One of them is Daruttauhid Islamic boarding school, Senori, Tuban. To make the action done and developed by Kiai Noer inspire other Islamic boarding schools in the form of ecological awareness based on religious spirit, this study describes the epic and emic aspects of Kiai Noer's efforts in formulating and implementing the kalam rimba (Mahzumi 2018).

\section{The Causes of Human and Nature Separation}

Alienation of nature causes humans to be accused as the actor behind the environmental crises at the global level. It is due to humans' perspective placing the entity outside themselves as a separate object because of the dualistic paradigm influence that characterizes modernity. Materialistic desire causes humans to fall into exploitative behavior. This behavior threatens the existence of nature and the surroundings. Industrialization emerges due to economic reasons and human needs fulfillment, which destroys the harmony between human and nature. Indeed, humans will never be satisfied with their desires and needs, as long it is still within the moderate and not excessively (Q.S. al-Furqân [25]: 67). Therefore, a paradigm plays the role of a controller and a director, so that the relation between human and nature is always in harmony. The philosophical-cosmic paradigm rooting in religious spirituality can be a breakthrough to reclaim the relation between both; universe and humans. Here, the separation of the two entities is more due to human needs.

The harmonious relationship has been pursued since human history began. It always went up and down until the modernism placed the relationship in a crisis. The anthropocentrism carried by modernism takes 
over the paradigm mainstream of modern humans thinking. The condition of the crisis began since Rene Descartes proposed a thesis on the dualism of substance, that the essence of mind and body are understood separately. The dualistic mindset leads humans to be separate entities from entities outside themselves. According to Plumwood, the dualistic mindset indirectly causes human separation from nature. It tends to put humans as "outside" and "above" the inferior nature so that it leads to human destructive behavior to nature (Plumwood 2002, 4). Because of the mindset, modern humans always view to separate and to differentiate from all entities in the universe. When it happens, the domination will speak up and take control.

In response to the sharpening dualistic mindset that engages humans and has a significant effect on environmental damages, David Pepper in his book Eco-Socialism - from Deep Ecology to Social Justice, presents a Marxist dialectic view of the relationship between society and nature that both mutual relations are intertwined to complete and implicate each other (Pepper 1993, xi-xiii). Humans who fail to recognize their existence are individuals who are unable to unite subject and object as one complementary form so that they will be controlled by their greed. The views that tend to be anthropocentric and positivistic from modernity were then suggested by many post-modernism figures to be reviewed, one of which was reviewed by Seyyed Hossein Nasr. This thinker offers a conception that human religiosity and spirituality can be the last hope for the ecological movement amid the rampant science and industrialization. One of the concepts is the belief in natural sacredness or the concept of wahdat al-wujûd which means feeling the presence of the Creator in every creation must be resurrected so that human history is saved (Nasr 1968; 1998).

\section{Discourse on Green Islamic Boarding School (Pesantren), Kiai Noer and Ijtihâd Kalam Rimba}

One of the responses to various problems arising and related to the environmental crisis is the emergence of an ecological movement. It is a movement containing a vast network of individuals and groups that mutually bind in a collective action to gain or pursue benefits for the environment (Roots 2002; Khitam 2011, 18). This definition is dominated more by ecological movement ideas from activists of non-governmental organizations or intermediary institutions across countries and political 
parties. The flow of this movement also exists at all levels, local, national, and international. The cause of this communal action was more influenced by the similarity of ideas among the involved actors. In the pesantren community, the belief in values in Islam that is inherent or in Max Weber's term called "verstehen" can be used as the basis for the ecological movement that emerges collectively.

The ecological movement can be divided into three variants: First, the ecological movement, which is a product of cultural and structural factors that appeared independently in response to the surrounding environment. Second, the ecological movement places the pattern and influence of mediation in environmental lobbies, both from the role of media and scientists. Third, the ecological movement appears as a reflection and response to the worsening environmental conditions, so that it becomes the main focus of the movement (Garner 1996). In identifying the ecology of the movement typology, it needs to be seen from several points of view: First to see from the side of interests and causes underlying an ecological movement. Lowe and Goyder distinguish it into two movements; emphasis and promotional movements. The emphasis movement is a movement that has gained success, or at least what they have been fighting for so far has paid off. While the promotional movement is only limited to conducting campaign efforts and calling for an ecological paradigm change (Garner 1996). Second, identification can also be done by looking at the focus of an ecological movement; environmental issues become the primary focus or only the secondary focus of the movement. Third, identification can also be seen based on the geographical impact created by an ecological movement, whether the actions done are local, national, or international. Fourth, the identification way of an ecological movement typology can be done by looking at the issues fought by the movement. The variants of the issue can be in the form of conservation, recreation, amenity, and resources.

A description of the identification of ecological movement typology, the environmental ethics concept also recognizes the platform of deep ecology, namely a philosophical view based on the sacred relationship between earth and other creatures. Deep ecology is an international movement encouraging the continuity of the universe future can be maintained, besides the ethics can also be a guide or direction for daily activities that relate humans and the natural environment as a unified ecosystem. This type of ecology continues to demand an investigation and research on the role of humans on earth, as well as requiring an analysis of 
unsustainable development practices, decreasing levels of human consumption, conservation, and restoration of ecosystems. The platform of deep ecology was first introduced in the 1970s, as a reaction to the limited operational and political conceptions imposed by liberal ideology and conservative institutions when carrying out environmental reforms.

This new ecological paradigm views the world holistically, which states that the world as a whole is unity and integrity, not partial and sporadic. It was initiated by the Norwegian philosopher, Arne Naess in the early 1970s to distinguish shallow environment and deep ecology. Arne's contribution is widely accepted as a very useful term for referring to the main division in contemporary thought over the environment. Devall and Sessions tried to adapt the two norms proposed by Naess, namely selfrealization and biocentric equality. Devall and Sessions put self-realization as a vision of real work or working hard to become a meaningful individual rather than to be an ego-materialist isolated individual. This practical form encourages the emergence of new ethics, namely to be (das sollen) or to do, no longer to try or to own (Luke 2002).

The second norm is the bio-centric norm; everything has the same right to live and develop and achieve an independent individual form. Keraf mentions several principles of the bio-centric norm. The first principle is the recognition that every living thing has equal status, integrity, and dignity. The second principle is the recognition that the human position unites with nature, not above or separate. The third principle is the recognition that the actualization of selfhood by humans is done by establishing communication and interaction with all entities outside them. The fourth principle is that humans recognize the biological pluralism that mutually binds and needs each other. The fifth principle is the formulation of a political system that contributes and encourages the creation of ecological harmony (Keraf 2002).

Deep Ecology Platform, born in 1984, gave a new style of the ecological movement characterized by global socio-politics-eco-philosophy. The basic principle lies in the combination of normative and philosophical eco-centrism used as an awareness spirit and an ecological movement. The basis is manifested in the following values (Keraf 2002): 1) Every entity on this earth, both human and non-human, has the value of an autonomous and independent individual to obtain welfare and development in life. Therefore, human dependence of non-human on non-human entity will be 
eroded; 2) Any non-human entity which has human utility belongs to materialistic qualification, so its diversity must be respected; 3) The right of natural utilization in order to live up the primary needs does not mean releasing humans to reduce biological diversity; 4) The growth of the human population does not necessarily give authority on the growth and progress of culture to disregard the environment; 5) Exploitation of entities outside human themselves exacerbates environmental conditions; 6) Changes in ecological rules is a must to affect economical, technological, and ideological governance; 7) A new perspective that emphasizes more on quality of life rather than materialistic mastery is expected to be the starting point of the paradigm alteration from anthropocentrism to ecocentrism.

Overall, Islamic boarding schools in Indonesia have been involved in an action that extends beyond religiosity dimension. Some of them have transformed into a more modern form in terms of curriculum and concentration of preaching, including responding to the environmental crisis happening. In his research, Husnul Khitam expounded that environmental issues have been the focus of several Islamic boarding schools such as in Al-Amin Sukabumi and Darul Ulum Lido Bogor (Khitam 2011). Both of them represent "the green Islamic boarding schools," focusing on environmental conservation. Through plans that have been suppressed for a long time and become the core subject of Islamic boarding schools, Islamic understanding is directed at answering profanation, not only a sacred zone. The hybridity of religious cognizance then formed a particular paradigm, and one of them was kalam rimba that became the ijtihâd of Kiai Noer in PP. Walisongo Tuban.

The transformation pursued by Kiai Noer, through the conception of kalam rimba, cannot be separated from the widespread of theological scope manifested by the reflection of the main actor, the capacity of Kiai Noer as an Islamic boarding school leader, to the values in the Quran and hadith. The perspective of the existence of forests as the dominant environment in PP. Walisongo has led Kiai Noer to ethics and ecological theology that integrates religion and tradition. Islam, as experienced by Kiai Noer, is very close to the conservation of nature and the environment. Furthermore, the Javanese cosmological tradition internalized in Kiai Noer has strengthened the vision and mission of the ecological movement initiated. All this time, the pesantren was known as a religious institution that could never escape the religious narrative, PP. Walisongo led by Kiai Noer could make a big leap with his ecological movement when he was able 
to bridge the rooted dichotomy in Islam; dictum fî al-âkhirah hasanah (religion) and fî al-dunyâ hasanah (science).

Several Islamic boarding schools concerned on ecological vision as studied by many researchers, and it has been mentioned in the introduction of this study. However, something is interesting from the ecological movement in PP. Walisongo. Generally, ecological movements in boarding schools are still classified as shallow ecological movements (Khitam 2011), while the ecological movement of Kiai Noer looks at significant changes and aspects of sustainability. It can be seen from the utilization of forest wood for large constructions such as halls, a large volume of chairs and tables, and furniture and walls of residents' houses entirely made of teak wood. Besides, the majority of residents as entrepreneurs and jobong workers (a limestone factory) that relies on forest wood as its fuel, we can imagine how unfriendly this Islamic boarding school and the community were to the forest. But now, PP. Walisongo, together with SMKN Kehutanan, become the moving spirit of forest conservation in Tuban.

The ecological awareness of Kiai Noer originated from the increasingly life-threatening condition of the forest because of human, dried up springs, and widespread barren land in the area of the school. Such conditions might cause landslides or other ecological disasters such as flood and drought. Through religious understanding, Kiai Noer began to think about how to overcome the tragic environmental conditions. The enlightenment of the environmental conditions led Kiai Noer to build a vision of saving the forest by doing reforestation, maintenance, and augmentation of plants on the area around the Islamic boarding school. Together with his students, Kyai Noer also conducted soil conservation on life-threatening and unproductive land and saved springs in forests mostly preserved by Perhutani. Moreover, Kiai Noer thought the sustainability of conservation of nature and the environment, initiated by inviting the forestry authorities, namely Pejabat Pemangku Hutan in Tuban to cooperate in establishing a forest-oriented formal school (Kiai Noer 2016).

The capability of Kiai Noer as the main actor determines the success of the planned ecological movement. In students and community's point of view, Kiai Noer is a charismatic figure whose fatwa is obeyed. Besides, the social structure built in PP. Walisongo is also one of the factors in how the transformation process works. The acceptance of Kiai Noer's idea by his students and the community towards save the forest was determined by good social relations. Geographical and sociological conditions are other 
factors that influence the success of the ecological movement. The existence of PP. Walisongo, located in a rural area with a relatively homogeneous culture, is the key to ease community transformation. The process of change in the school in seeing environmental problems becomes a unique thing. This is caused by the subject in this boarding school concretely changes the perspective that places all entities outside individuals, the forest and its substances in an equal relationship. This perspective is known as deep ecology movement.

The continuum process of kalam rimba as it was initiated by Kiai Noer happened through three stages: First, internalization. Islam teaches various principles that underlie Muslim daily activities, including the principle of environmental conservation. The ecological principles taught by Islam inspiring Muslim understanding in which then builds ecological awareness. In kalam rimba, the process of internalization occurred when Kiai Noer discovered an ecological awareness from the verses in the Quran and hadith, which emphasized the responsibility of Muslims as the khalifah (representation) of Allah. This ecological awareness is reinforced by the Javanese cosmological tradition that is understood by Kiai Noer (Mahzumi 2018). The internalization is the first step that determines the process of values deposition of individuals, which involves interpersonal interactions. Both students and the community who have personal and collective involvement in this ecological movement interpreted the concept of kalam rimba through Kiai Noer's instructions by considering the facts of forest degradation and the threat of ecological disasters that could happen any time. This process is called objectification. Third, kalam rimba continuum ended with a change in attitude and actualization of ecological awareness of the community in the form of efforts to save the forest and the establishment of SMKN Kehutanan.

Based on those three processes, ecological movements in PP Walisongo can be classified into "deep ecology". It contains an ontological foundation as the results of induction on the ecological principles taught by Islam and the Javanese cosmological tradition initiated by Kiai Noer. Besides, the ecological movement in the school also spread to the students and the local community. It increases collective awareness, which led to changes in understanding and attitudes to maintain harmony with the forest. The sustainability aspect is another reason that the ecological movement initiated by Kiai Noer is classified as "deep ecology". Through 
the establishment of SMKN Kehutanan, Kiai Noer pairs the ideas of kalam rimba from theoretical to practical one. As long as SMKN Kehutanan operates, the transfer of kalam rimba will always produce students who have ecological awareness and are ready to involve themselves in the forest and environmental conservation movement. It was revealed from the action of reforestation, conservation, etc. by students from SMKN Kehutanan.

\section{From Eco-theology Contemplation toward Forming Forest Conservation Students}

To elaborate kalam rimba initiated by Kiai Noer, here will be described the process of induction of Islamic texts which later strengthened the ecological facts in which PP. Walisongo is located. It was started by Kyai Noer's reflection on Q.S. al-Baqarah [2]: 30 when Allah had a discussion with His angels that He would create Khaliffah (representation) of Allah on the Earth. The great plan for the creation of man was objected by His angels. Based on their predictions, humans will only be a cause of damage and carnage on the earth. Jumhûr Mufassir said, the term khalifah in verse refers to humans. The theological reflection on this verse led Kiai Noer to a cognizance of the responsibility that Allah has given humans nature as well as the matters. That responsibility is an actualization of trust Allah has given to humans as khaliffah to sustain harmony and nature. The term khaliffah, according to Kiai Noer's means "leader, manager," and the term also confirms human identity as a retainer (Kiai Noer 2016).

Based on the contemplation of the term khalifah in Q.S al-Baqarah [2] verse 30, Kiai Noer thought about how to achieve that mandate. The forest as an environment at which Kiai Noer lives became the object he thought about. He contemplated the values of the forest for humanity. Those values are 1) Forest as pest deterrence for agriculture and plantations; 2) Forest as a life source; 3) Forest as a fortress from disasters, and 4) Forest as a sanctuary of economic assets (Mahzumi 2018). However, he experienced a squandered forest, whereas it is very much needed for humanity survival. The vast teak forest around PP. Walisongo does not necessarily build awareness of the forest values. The local community even speared the forest illegally because of the demands of the profession. Kiai Noer said:

"Previously, the majority of people here were limestone makers. The site to make it is called Jobong. Each Jobong requires around 1400 to 1500 cubic of wood once to burn limestone. It affected the nearby forest because to 
accomplish that needs of wood, Jobong's industrialists illegally took wood from the forest" (Kiai Noer 2016).

The forest damage around PP. Walisongo is truly seen when the spring resource is dried out since the community relies on the spring for their household and rice field. Kiai Noer investigated it and turned out that the cause of the dried out spring was the condition of the land around the location of the deforested spring. Kiai Noer's anxiety was then answered by the government represented by Perhutani, who invited him to work together to tackle the serious condition of the forest in Tuban. The collaboration was stated in the Memorandum of Understanding $(\mathrm{MoU})$ for the establishment of forest-oriented vocational education institutions. The MoU then followed up by launching SMKN Kehutanan whose management was handed over to Kiai Noer. The object of this school was surrounding communities who hang on their life from the forest. Kiai Noer stated:

"There is a dilemma faced by Perhutani when taking illegal loggers in the forest area owned by Perhutani. If it is too hard, it will have an impact on the economy of the community. While if it is left unhindered, severe forest destruction cannot be avoided. Therefore, education was chosen as a long-term solution to break the chain of community dependence on forest" (Kiai Noer 2016).

Theologically, the forest around PP. Walisongo delivered Kiai Noer to the conclusion that Allah had created this universe in detailed that human intelligence would not be able to reach the whole secrets within. It will utter ulûhiyyah and rubûbiyyah tawhîd. Besides, determinations to protect and preserve the forest in a theological perspective are also manifestations of human duty as servants ('abd) in the esoteric realm and charity in the exoteric realm. The forest values, as mentioned above, have an impact on the good among humans; even it is also useful for the entire creation considering the forest as the production of oxygen needed by all living creatures. That would certainly be worth the reward before the Creator.

Theological awareness of the values of forest and the empirical reality of the crisis appear from the sustainability of forest ecosystems in Tuban and Indonesia in general, Kiai Noer in collaboration with the government and Perhutani took the initiative to break the chain of causes of forest destruction through education. The establishment of SMKN 
Kehutanan is expected to be home for operating natural resources in the form of forest and be a site to cultivate forest squads who are aware of the importance of forest for life by emphasizing the aspects of religiosity. It approves that there is progress in the ecological movement initiated by Kiai Noer from theology to the theological action. Based on the perspective of environmental movement continuum, the transition process from theology to theological action pass through the stage of internalization, to objectification, ends in the application of concrete actions of forest conservation.

The vision to shape Muslim generations who have concern and responsibility for forest sustainability proves that Kiai Noer was serious in building an Islamic ecotourism paradigm. The awareness of maintaining human harmony with nature is a binding entity with tawhîd and sharia. Stability of realm and the afterlife matters in ecological movement initiated by Kiai Noer can be understood from his statement, "the eco-theological reflection we have conveyed is a consideration to establish a school that provides caring cadre, as well as being ready to work in the forestry sector, regarding to the fact that skilled people are needed in this field" (Kiai Noer 2016). The establishment of SMKN Kehutanan emphasizes that there must be an integration between realm and afterlife vision. Students in PP. Walisongo were directed to be a devout people by accomplishing their duties as khaliffah fi al-ard by caring for and preserving the forest. Also, they are also expected to fill the job in the forestry sector or other professions in various institutions that require skilled and competent people of forestry.

The progress in PP. Walisongo is not merely limited to concepts significant impact on changing society and having sustainability aspects in forest conservation determinations. From the information obtained, the community now realizes the urgency of forest conservation and the implications of forest destruction and its ecosystem for their lives. At least SMKN Kehutanan in PP. Walisongo has a large and significant influence in resolving the environmental crisis in that area.

Furthermore, SMKN Kehutanan will be able to improve the welfare of community later after the children around the Islamic boarding school graduating from school and work for Perhutani or government or private institutions that need skilled workers in the forestry sector. The efforts of Kiai Noer in transforming society to be forest conservators are not easy. In the beginning, Kiai Noer's intention to establish SMKN Kehutanan was challenged by a few people. It was stated by Kiai Noer, "everything that 
appears in the community will indeed invite pros and cons, even so with the establishment of vocational school in this Islamic boarding school" (Kiai Noer 2016).

Before establishing the forest-oriented vocational school, Kiai Noer has been starting his action by minimalizing the use of forest wood to build houses and other buildings in the Islamic boarding school. The practical step inspired the society to contribute to changing the dependency on forest wood. Besides, Kiai Noer often advised the local society, students, and his children to do the planting. As retold by his son, Gus Maya, "Father often told us (his family), students and the society to plant (especially teak tree), to replace stolen or illegally cut trees" (Gus Maya 2018). The simple advice was able to trigger forest conservation in the region. The movement got massive after the establishing of SMKN Kehutanan. Founding the school in 2008, Kiai Noer prioritized students from around the Islamic boarding school whose parents still depended on the forest. Then, Kiai Noer evolutionally helped the students to get jobs after their graduation.

The effort was not difficult since Kiai Noer and SMKN Kehutanan already had a Memorandum of Understanding with the graduate users, both from the government and private companies, especially Perhutani. Kiai Noer said:

"al-Hamd li Allâh until 2016 we have distributed more than 500 graduates around Indonesia to work in the forestry and environmental field. The condition cut the generation chain among local peoples working as Jobong workers and depending on their lives on forest products illegally. Certainly, the strategic step has a positive impact on forest conservation and preservation in Singgahan subdistrict and around it. The students have been trained since the first time to protect the forest from the human bad impact, such as illegal logging and other ecosystem destructions" (Kiai Noer 2016).

Kiai Noer also taught the students self-defense to protect themselves from criminals when they work in the forest. Theologically, the action is an implementation form of a religious order, wa'mur bi al-ma'rûf wanha 'an almunkar (fight for the truth and prevent evil deeds).

The awareness of eco-theology importance introduced by Kiai Noer in PP. Walisongo inspired other Islamic boarding schools to involve in a similar ecological movement. The researcher found it in Daruttauhid Senori Islamic Boarding School Tuban. Its students realized that every 
human being, especially Muslims, is responsible for optimally manage nature. Allah has ordered human as his successive authority in the world (Khaliffah fi al-Ard) as stated in Q.S. al-Baqarah [2]: 30, Luqmân [31]: 20, alAn'âm [6]: 165, and Ibrâhîm [14]: 32-33. Generally, the verses explain that the creation of nature is for human interest. However, they have to be responsible for nature sustainability by keeping the use and maintenance in balance. Therefore, each person needs to do the order wisely since the Quran states that human being is the cause of natural destruction. It is stated in Q.S. al-Shûrâ [42]: 30 and al-A'râf [7]: 56.

\section{The Continuity in Preaching Natural Sacredness}

Kiai Noer was not alone in his effort to campaign forest ecologicalcommunal awareness to the society. One of his son, Abraham Naja, called Gus Naja in his youth was involved in spreading ecological awareness to society through his community, Maos Selawat with the member more than 1000 members in various cities such as Tuban, Bojonegoro, Lamongan, Gresik, and part of Central Java. To the members of Maos Selawat, Gus Naja often emphasized the urgency to harmonize human relation with nature as observed by the researcher in the Maos Selawat routine activity held in the cemetery complex of Condro Dipo Gresik on Sunday, October 24, 2016. In the event, Gus Naja delivered a theological message that every Muslim needs to pay attention to ecological ethics.

Started with reading selawat, people including teenagers and adults were carried by the atmosphere. They read selawat duas such as selawat munjîyât, selawat nârîyah, and other selawats. After the ritual of dua reading, Gus Naja started his preach for the guests. At first, he delivered the importance of selawat. Selawat is an important deed considered by Allah when it is done for several reasons namely Allah in Quran states that He and His angels confer blessing upon the Prophet Muhammad (Q.S. alAhzâb [33]: 56). It is a practice considered as a worship gaining reward from Allah even though it is done only for showing off (riyâ'). It also guarantees Muslim to get intercession from Prophet Muhammad; it also makes Allah grants people's duas. There are many other benefits of reading selawat as long as it is read consistently (istiqâmah).

In the moment of reflection, Gus Naja advised his members to maintain their ethics toward nature as taught by their ancestor. People should be down to earth toward other creatures. The universe is the 
creation of al-Khâliq (The Creator). The mountains, seas, forests are the creation of Allah. Therefore, Muslim as His representation on Earth must behave to other creatures including their environment. The role model of ecological ethics has been given by earlier ulemas. They did tawâsul (read alFâtihah) for the Prophet Khidir when they were on the sea; they did tawâsul for the Prophet Ilyâs when they were on the mountain, and they did tawâsul for the Prophet Nûh when they were on land. The ritual shows the form of awareness on the natural sacredness. Humans always have a supernatural bond with their natural environment. Javanese people called it as danyang (guardian).

The natural awareness introduced by Gus Naja aimed to build the cosmic awareness among the followers of Maos Selawat to keep the relation with their surrounding nature in harmony. To the researcher, Gus Naja told:

"People can be called as modest when they can adapt with their environment, treat the nature well, furthermore, ethics is directly introduced by Islam through the ritual of tawâsul for prophets, such as conducting tawâsul for Prophet Khidir on the sea and conducting tawâsul for Prophet Ilyâs on the mountain" (Gus Naja 2016).

The cosmic awareness was taught by Kiai Noer to all his children and students so that they can behave with their environment. All of his children consistently advised the society to maintain their relationship with nature since it is an image (tajallî) of God himself. As quoted in Instagram by one of Kiai Noer's son, RA. Armaya Mangkunegara:

"They read tasbih. Praising the greatness of Allah, the Creator. They live with humans who always remember Allah. It is logic in this condition that the degree of spiritual happiness increases rapidly. Such a pity if it is ruined by some irresponsible peoples."

The ecological awareness of Kiai Noer, Gus Naja, and Gus Maya is following the perspective of Seyyed Hossein Nasr who stated that the anthropocentric paradigm based on materialism and secularism had brought natural sacredness degradation. Nature is only considered based on its quantitative aspect and its instrumental value to produce economic benefit as many as possible. The solution for the problem is by regenerating the sacredness of nature and science (scientia sacra), in which the metaphysical dimension of the universe should be reborn. The effort of 
regaining natural sacredness aims to return modern science to its metaphysical root. Only by admitting the natural pureness and qualitativequantitative aspect, nature will open its beauty and secret to human and eventually, the human will have a good relation with nature (Nasr 1996). Nasr's thesis is in line with White which offers people to move from monotheism to pantheism as found in Eastern religious traditions by building cosmological awareness that has spiritual insight and natural sacredness (White 1967).

\section{The Inspiration of Kalam Rimba for Islamic Boarding Schools Surrounding PP. Walisongo}

The idea of kalam rimba proposed by Kiai Noer has inspired nearby Islamic boarding schools as occurred in Daruttauhid Al-Hasani Islamic Boarding School where an eco-theological paradigm, similar with kalam rimba, can be seen in some students' activities such as "Jumat Bersih" (Tidying activity on Friday). The program aims to build students' responsibility toward their environment. Working together, the students along with their teachers and the boarding school leader involved in the action to clean and take care of their school environment. The students share the works such as planting trees in the school area, watering the existing plants, cleaning all guts and rooms, and collecting and sorting the garbage into organic and inorganic ones. The organic garbage is processed into compost. Meanwhile, some of the inorganic garbage is recycled, and some of them is given to scavengers.

Besides Jumat Bersih, the subjects in Daruttauhid Islamic boarding school are trained to have an ecological awareness by directly practicing using teak forest area of the school. Gus Hilmi (One of kiai board in Daruttauhid Islamic boarding school) said, "besides the utilization of its wood for building the school, the teak area aims to train students in planting, taking care and harvesting teak" (Gus Hilmi 2018). Based on the obtained information, the school has at least 1,000 teaks. Therefore, ecological awareness is built in the character of the students and also all subjects in Daruttauhid Islamic boarding school.

According to Gus Hilmi, ecological awareness in Daruttauhid was inspired by Kiai Noer's action. Furthermore, SMKN Kehutanan found by Kiai Noer is a concrete form of forest rescue as an environmental basis in Singgahan subdistrict. When Kiai Noer introduced kalam rimba as an ecological paradigm based on religious value to save the forest, then 
according to Gus Hilmi, Daruttauhid Islamic boarding school has its theological concept on how important the conservation is generally for Muslim and particularly for the school subject. He stated that the Quran describes a prosperous country in baldat tayyibah wa rabb ghafûr. A supporting factor needed by a country to realize the vision is by taking care of the environment. It is impossible for a country to be prosperous when it ignores the environmental conservation. It is similar to the forest. When we do not maintain it, its existence will harm human such as the potency of landslide due to exploitative deforestation ignoring the environmental impact. From the reflection of the Quran, it is obligatory for Muslims to rescue and conserve the environment. They have to participate, even in a small portion, in maintaining and protecting the earth from destruction (Gus Hilmi 2018).

Gus Hilmi furtherly explained:

"In Tuban where Daruttauhid Islamic Boarding School exists, teak becomes the top product in the region. Many people are interested in taking benefit from the commodity due to its price. Moreover, the wide state forest has minimum monitoring and security. Some unscrupulous people did teak illegal logging or deforestation for their benefit. They usually ignored the impact of their deeds for the environment. Islamic boarding school should participate in building people awareness so that they could be wise toward their environment. Its existence near the society can be utilized to increase ecological awareness based on Islamic values. It may be involved in formulating for example, forestry figh, or it may use its unique scientific basis for supporting environmental conservation" (Gus Hilmi 2018).

From the earlier description, the study considers enormous Islamic boarding schools in Indonesia have a great potency to be actively involved in Islamic based ecological movement as formulated by some scholars (Nasr 1968; Khalid 2010). It can be done by building a network among Islamic boarding schools having a similar vision to trigger environmental conservation under natural source potency in the area. Islamic boarding school located in seashore can initiate sea conservation. Meanwhile, an Islamic boarding school near a forest can participate in conserving the forest. Religious instrument and social power of Islamic boarding schools can be used optimally for environmental programs such as "green preaching" and ecological paradigm scientific formulation aiming to initiate 
social awareness on the importance of maintaining the environment since it is an inseparable part of the religion (Mohamed 2014, 316; Latour 2009).

\section{Conclusion}

The ecological movement nowadays, urgently needs paradigm change from pure ecology to religious aspect involvement. The antithesis emerges when the ecological action which only depends on the ecological aspect fails to give a significant impact on the treatment of environmental crisis faced by human beings. The anthropocentric (human is the center) general opinion of the society, instead of cosmocentric one (nature is the center), leads to human and nature disharmony relation. Even though most people have religion; the fact shows that the religious belief is often asymmetric with individual behavior. The religion teaches the responsibility to conserve nature. In contrary, human disobeys the teaching due to their materialistic needs, and they ignore the relation balance among human, nature, and God. Religious people often destroy and exploit nature. Therefore, it is important to have a re-effort to make nature sacred and make it as an interconnected entity.

The hadith mentioned in the introduction becomes a theological foundation implicating on Muslims' awareness and ecological behavior. It also occurred on KPP. KH. Noer Nasroh Hadiningrat, the leader or "Forest Warrior" of PP. Walisongo Tuban. The theological implication transformed from the forest destructor into forest conservator. After conducting theological reflection, people are led to create students who have awareness of the forest existence. The integration of dogmatical belief and ecology brought Kiai Noer and local Perhutani to establish SMKN Kehutanan as a people empowerment and a practical form to generate forest conservation students to prevent forest destruction in Tuban. The ecological movement by Kiai Noer was supported by his family, students, and local society. It also inspired other Islamic boarding schools in the region to formulate theological principles as the responsibility as a Muslim generally and as an Islamic boarding school particularly to fulfill human responsibility as God representation on earth as stated in Quran and hadith.

\section{References}

Arnez, Monika. 2014. "Shifting Notions of Nature and Environmentalism in Indonesian Islam." In Environmental and Climate Change in South 
and Southeast Asia How are Local Cultures Coping?, ed. Barbara Schuler. Leiden: Brill, 75-101.

Aulia, Rihlah Nur, Dian Elvira Nanda Isnaini, and Umi Khumairoh. 2017. "Pengelolaan Lingkungan Berbasis Pesantren (Studi Kasus di Pondok Pesantren Nurul Hakim Lombok).” Hayula: Indonesian Journal of Multidisciplinary Islamic Studies 1(2): 229-44.

DOI: https://doi.org/10.21009/hayula.001.2.06

"BNPB: Selama 2018, Ada 1.999 Kejadian bencana." 2018. https://nasional.kompas.com/read/2018/10/25/22572321/bnpbselama-2018-ada-1999-kejadian-bencana (September 21, 2018).

Fata, Ahmad Khoirul. 2014. "Teologi Lingkungan Hidup Dalam Perspektif Islam." Ulul Albab: Jurnal Studi Islam 15(2): 131-47.

Garner, Robert. 1996. Environmental Politics. London: Harvester Heatsheaf.

"Ini Penyebab Longsor di Ponorogo Hasil Penelitian Tim UGM." 2017. https://news.detik.com/berita-jawa-timur/d-3464135/ini-penyebablongsor-di-ponorogo-hasil-penelitian-tim-ugm (September 21, 2018).

Islam, Md Saidul. 2012. "Old Philosophy, New Movement:The Rise of the Islamic Ecological Paradigm in the Discourse of Environmentalism." Nature and Culture 7(1): 72-94.

DOI: https://doi.org/10.3167/nc.2012.070105

"Kaleidoskop Bencana Lingkungan 2012: Degradasi Hutan Melaju, Banjir Menerjang Manusia."

2012.

https://www.mongabay.co.id/2012/12/28/kalesidoskop-bencanalingkungan-2012-degradasi-hutan-melaju-banjir-menerjang-manusia (September 21, 2018)

Keraf, A. Sony. Etika Lingkungan. Jakarta: Penerbit Buku Kompas, 2002.

Khalid, Fazlun. 2002. "Islam and the Environment." in Encyclopedia of Global Environmental Change, ed. Peter Timmerman. Editor-in-Chief Ted Munn. Chichester: John Wiley \& Sons. www.ifees.org. (August $16,2016)$.

Khalid, Fazlun. 2010. "Islam and the Environment-Ethics and Practice: An Assessment." Religion Compass 4(11): 707-16.

DOI: https://doi.org/10.1111/j.1749-8171.2010.00249.x 
Khitam, Husnul. 2011. "Manifestasi Nilai Teologi dalam Gerakan Ekologi: Studi Kasus di Pesantren Al-Amin Sukabumi dan Pesantren Darul Ulum Lido Bogor.” Thesis. Program Pascasarjana Institut Pertanian Bogor.

Khitam, Husnul. 2016. "Kontekstualisasi Teologi sebagai Basis Gerakan Ekologi." DINIKA: Academic Journal of Islamic Studies 1(2): 143-64.

DOI: http://dx.doi.org/10.22515/dinika.v1i2.62

Kung, Hans. 2007. Islam: Past, Present and Future. A Oneworld Book.

Latour, Bruno. 2009. "Will Non-humans be saved? An argument in ecotheology." Journal of the Royal Anthropological Institute 15(3): 45965.

DOI: https://doi.org/10.1111/j.1467-9655.2009.01568.x

Luke, Timothy W. 2002. "Deep Ecology: Living as if Nature Matered: Deval and Sessions on Defending the Earth." Organization and Environment Journal 15(2): 178-86.

DOI: https://doi.org/10.1177/10826602015002005

Maghfur, M. 2012. "Pendidikan Lingkungan Hidup dan Masa Depan Ekologi Manusia." Forum Tarbiyah 8(1): 57-71.

Mahzumi, Fikri. 2018. "Renungan Ekoteologis KH. KPP. Noer Nasroh Hadiningrat di Pesantren Walisongo Tuban.” ISLAMICA: Jurnal Studi Keislaman 12(2): 333-57.

DOI: https://doi.org/10.15642/islamica.2018.12.2.315-339

Mangunjaya, Fachrudin, M. 2005. Konservasi alam dalam Islam. Jakarta: Yayasan Obor Indonesia.

Matthew, T. Riley. 2014. "A Spiritual Democracy of All God's Creatures: Ecotheology and the Animals of Lynn White, Jr." In Divinanimality: Animal Theory, Creaturely Theology, ed. Stephen Moore. New York: Fordham University Press: 241-260.

Mohamed, Najma. 2014. "Islamic Education, Eco-ethics and Community." Studies in Philosophy and Education 33 (3): 315-28.

DOI: https://doi.org/10.1007/s11217-013-9387-y

Muslim, Abû Ḥusayn. 1991. Șaḥ̂h Muslim. Beirut: Dâr al-Kutub al-'Ilmiyah. 
Nasr, Seyyed Hossein. 1989. Knowledge and The Sacred. New York: SUNY Press.

Nasr, Seyyed Hossein. 1968. Man and Nature: The Spiritual Crisis in Modern Man. London: Allen and Unwin.

Nasr, Seyyed Hossein. 1996. Religion and the Order of Nature. New York: Oxford University Press.

Özdemir, Ibrahim. 1998. "An Islamic Approach to the Environment." www.home.cogeco.ca (August 10, 2016)

Pepper, David. 1993. Eco-socialism: From Deep Ecology to Social Justice. London: Routledge.

Plumwood, Val. 2002. Environmental Culture: The Ecological Crisis of Reason. New York: Routledge.

al-Qardhawi, Yusuf. 2002. Islam Ramah Lingkungan. Trans. Jakarta: Pustaka al-Kautsar.

Roots, Cristopher. 2002. Environmental Movement Local, National and Global. London: Frank Cass Publisher.

"Statistik Pesantren."2018. http://pbsb.ditpdpontren.kemenag.go.id/pdpp/ (September 21, 2018).

Udin, Nur Hidayat Wakhid. 2016. "Perspektif Islam tentang Resiprositas Hubungan Pelestarian Alam dan Kehidupan Sosial.” Marâji': Jurnal Ilmu Keislaman 2(2): 355-81.

White, Lynn Jr. 1967. "The Historical Roots of Our Ecological Crisis." Science 155, March 10.

Interview with Kiai Noer (KH. KPP. Noer Nasroh Hadiningrat), Tuban, July 17, 2016.

Interview with Gus Naja (RM. Abraham Naja Mangkunegara), Gresik, October 24, 2016.

Interview with Gus Maya (RM. Armaya Mangkunegara), Tuban, October 19, 2018.

Interview with Agus Hilmi Badruttamam, Tuban, September 21, 2018. 